\title{
Learning from Rohingya Refugee Repatriation to Myanmar
}

\author{
K. C. SAHA
}

\section{Abstract}

The author examines the role of the United Nations and the international community in establishing criteria for the return of Rohingya refugees to Myanmar from Bangladesh. This study highlights the importance of the international community in establishing standards and supporting the return, even in cases where the national governments involved (Myanmar and Bangladesh) have never signed the un Convention on the Status of Refugees. The author concludes that the repatriation of Rohingya refugees from Bangladesh has been relatively successful, and that the pattern seen in this return could be usefully replicated in order to bring about the voluntary repatriation of other refugee groups to Myanmar.

\section{Résumé}

L'auteur examine le rôle joué par les Nations Unies et la communauté internationale dans l'élaboration de critères pour le retour de réfugiés Rohingya du Bangladesh vers le Myanmar. L'étude souligne le poids considérable dont pèse la communauté internationale lorsqu'il est question d'établir des critères et de soutenir le processus de retour, et cela, même dans des cas où les gouvernements concernés (le Myanmar et le Bangladesh) n’ont jamais signé la Convention des Nations Unies sur le statut des réfugiés. L'auteur conclut que cette opération de rapatriement de réfugiés Rohingya du Bangladesh s'est relativement bien passée et que la tendance observée dans ce retour pourrait être utilement reproduite afin d'obtenir le rapatriement volontaire d'autres groupes de réfugiés vers le Myanmar.

\section{Causes of the Refuge Displacement}

7 he Arakan region of Myanmar, like the Kachin state, the Karen state, and the special division of the Chins, has witnessed insurgency since Myanmar's independence in 1948. The Rohingyas are Muslim descendants of Arab and Persian traders who settled in the Arakan region, and there has been intermarriage with the indigenous population over several hundred years. The population of the Muslims in this region is about 3 million. The region has a common boundary with Bangladesh, separated by the Naaf River and interspersed with forests and hills. The Arakan province has been traditionally under the influence of Bengali culture because of its proximity to Bangladesh.

Even prior to 1992, there had been several displacements of the Rohingyas, the major one being in 1978, when the Myanmar government announced that there was an alarming increase in the number of illegal migrants from Bangladesh, in the Arakan region. A campaign disguised as a search for illegal immigrants produced a wave of refugees to Bangladesh. "At least 130,00o Rohingyas had deserted their homes and went over to Bangladesh." The Myanmar authorities maintained that those who had fled across the border were Bangladesh nationals who had illegally entered Myanmar. However, under international pressure, the government agreed to accept the refugees from Bangladesh. An agreement for repatriation was signed with Bangladesh, and the Rohingya refugees were repatriated to Myanmar.

In Myanmar, during general elections in 1990, the Rohingyas supported the National League for Democracy (NLD), whose focus was termination of military rule in Myanmar. The military regime, under the State Law and Order Restoration Council (sLORC), negated the results of the general election and intensified its campaign against the ethnic minorities who supported the NLD. The 
Myanmar authorities alleged that the Rohingyas in general were aiding, abetting, and hiding the insurgents who were supporting an independent state of Arakan. "The authorities issued arrest warrants against 10,00o Muslim students for an alleged insurgency plot against the State." Subsequently the army terrorized the entire Rohingya population, who started deserting their homes. The un high commissioner for refugees, Sadako Ogata, in a statement issued on February 14, 1992, said that "she was deeply concerned about the conditions in Myanmar that were forcing people to flee at the rate of 400 to 600 a day." ${ }^{\prime 3}$ The uNHCR Technical Mission, which inspected a large number of encampments in Bangladesh, reported that "the refugees were streaming into the country at a rate of thousand a day. Unless the conditions improved in Myanmar, their numbers were expected to increase."4

"About 210,000 Rohingya refugees reached Bangladesh by 1992."' Amnesty International reported that the military regime had seriously violated the human rights of ethnic minorities in Myanmar. An Amnesty fact-finding team sent to interview Rohingya refugees in Bangladesh confirmed reports of widespread human rights abuses, including torture and murder. "The U.S. Committee for Refugees which visited Bangladesh in February, 1992, also reported that the refugees had fled because of human rights abuses committed against them by the Myanmar authorities. Their homes and mosques were destroyed, their lands appropriated, their men were subjected to forced labour and physical abuse. The Myanmar Military's actions were part of a deliberate campaign of terror aimed at driving the Rohingyas out of Myanmar.”' In the February 1993 Report to the United Nations Commission on Human Rights, the uN special rapporteur on Myanmar concluded that Muslims in the state were at high risk.

\section{Steps Taken for Repatriation of the Refugees}

The influx of such a large number of refugees posed serious problems for Bangladesh. It expressed its serious concern to the Myanmar regime. Prime Minister Begum Khaleda Zia pleaded that "the Myanmar authorities must take back the Muslim refugees who fled to Bangladesh to escape military crackdown. Bangladesh cannot look after the refugees for long. They are citizens of Myanmar and they will have to return to their country."

The mediation of un Undersecretary General Jan Eliasson to resolve the refugee problem between Bangladesh and Myanmar produced results. Myanmar agreed to send its foreign minister, U Ohn Gyaw, to Dacca for talks with his counterpart on the modalities for the return of over 210,00o Rohingya Muslims. Myanmar authorities made the assurance that that it was prepared to accept refugees who had evidence of prior residence in Myanmar. An agreement calling for "safe and voluntary" repatriation of refugees was signed in early 1992 by the foreign ministers of both countries. An agreement on technical modalities to be followed in bringing repatriation, signed by officials of both countries, provided methods for checking the identity of the refugees. Under the agreement, repatriation was to start on May 15, 1992. But repatriation could not start on the decided date because a majority of the refugees were against any return. However, talks at the official level between the two countries continued. A proposal to involve the UNHCR during repatriation was rejected during the talks held on July 30, 1992. However, later the two countries agreed to involve the UNHCR in the repatriation of refugees. Both countries further agreed on a four-point formula to create congenial conditions in Arakan for the repatriation of refugees. The agreement reached on August 23, 1992, provided:

1. Azan (call for prayer) over loudspeakers will be allowed in mosques in the Muslim majority Myanmar province. 2. The Rohingyas will be allowed to move freely from village to village in their homeland, ending earlier restrictions.

3. The Rohingyas from their shelters in Bangladesh can travel to Arakan to see for themselves the conditions created for them and then come back to camps.

4. Those Rohingyas who do not possess a citizenship certificate can apply for it after returning home. ${ }^{8}$

Repatriation began in batches, in early September 1992. But soon there were protests from a large number of refugees opposed to repatriation. "The refugee camp at Dhuapalong built with un assistance was the scene of bloody clashes between refugees and the Bangladesh security forces which left 6 Myanmar Muslim refugees dead, scores injured and over 200 arrested."' The protests of refugees continued in other camps also. "The inmates of Naikhangchari camps at Gundum went on a rampage, damaging the camp office. The refugees demonstrated inside the camps opposing repatriation.." ${ }^{10}$ Chaos and confusion prevailed in the camps. "The armed refugee militants who were opposing the process of repatriation virtually seized control of camps at Dhechuapalong after the rumour was spread that a fresh group of refugees would be sent to Arakan. Tension was also mounting in camps at Nayapara, Balukhali, Dhum, Sailor Dheba, Dhuapalong and Rangikhali areas near Cox's Bazar in the Chittagong Hill Tract. Large contingents of Bangladesh police raided sev- 
eral camps on October 10, 11, and 12, 1992, to apprehend the rebels and made number of arrests." came quite tense in a number of camps. "At least 70 people including 15 policemen were injured in a fierce gun battle between security forces and militant Muslim refugees on December 5, 1992. The clash took place when a group of 1300 refugees willing to return to Arakan, were being taken to a transit camp in Cox's Bazar for repatriation. Some of the refugees fired from automatic weapons. The security forces hit back by firing 40 rounds. Tension continued to prevail at the Nayapara refugee camp, after the violent incident."

The Bangladesh government had banned any political activity by the refugees, but their leaders secretly continued their activities. Two organizations of the Rohingya Muslims-Rohingya Solidarity Organization (Rso) and the Arakan Rohingya Islamic Front (ARIF) — were active. Their aim was to set up Rohingya settlements in different parts in Cox's Bazar in Bangladesh and to launch a movement to establish a Muslim Rohingya state, with the help of international assistance. These organizations had a considerable influence over the refugees in the camps.

The un high commissioner for refugees, Ms Ogata, appealed to the prime minister of Bangladesh to stop the forced return and to allow the UNHCR free access to the refugee camps. The UNHCR had pulled out of the repatriation towards the end of November 1992, after allegations that many refugees were sent home against their will. Bangladesh, on the other hand, accused the UNHCR and some Western relief agencies of discouraging refugees from going back to their homes. A new memorandum of understanding was signed between Bangladesh and the UNHCR, which provided that refugees willing to return home would themselves register their names for repatriation, before being taken to one of the three transit camps on the bank of the Naaf River. The new agreement gave UNHCR officials unlimited free access to the refugee camps. Under the previous system, camp officials had drawn up a list of volunteers from names provided by refugee headmen. But aid agency workers often claimed that the headmen were bribed or forced to provide names.

The refugee repatriation became further complicated when a number of refugees deserted the camps. It was alleged that local communal organizations instigated the refugees to desert the camps, and as a result 20,000 refugees ran away from camps in Cox's Bazar and Bandarban to hilly areas. Several hundred local residents of Maheshkhali area demonstrated before the police station on August 3, 1993. The demonstrators alleged that "about 400 Rohingya refugees had so far entered the Maheshkhali area after fleeing their camps. They urged the authorities con- cerned to take back the refugees to their assigned shelters." ${ }^{\prime 3}$

Repatriation involved several rounds of talks between officials of the two countries. The fifteenth round was held on August 31, 1993. Repatriation, which began in September 1992, continued in batches throughout 1993. During a cyclone on May 5, 1994, in which twelve out of nineteen camps were razed to the ground, eighty-six refugees were killed. The government suspended repatriation in view of the losses suffered by the refugees in the cyclone. Between August 1994 and March 1995, large-scale repatriation was completed. "But the repatriation came to a virtual halt in April 1995 when Myanmar authorities suddenly started talking about re-verification of individual refugees who had earlier been cleared for repatriation. Thus repatriation of 54,000 remaining refugees became uncertain." ${ }^{14}$

In the beginning of the repatriation process, the Myanmar authorities offered clearance to refugees on the basis of a "runaway list," which they themselves had prepared. But they later admitted that the runaway list was far from accurate. "About 42,000 cases were pending as they did not pass the scrutiny carried out by the Myanmar authorities. If one member of the family failed the scrutiny, the whole family was stranded. The files of the failed individuals were sent to the Bangladesh authorities for more particulars. And such a process of re-verification sometimes took as long as one year." ${ }^{15}$

Repatriation continued in small batches in 1996 and 1997. During repatriation there were fresh cases of Rohingya Muslims from Myanmar coming to Bangladesh. "Bangladesh Rifles 39 Battalion had pushed back a group of 81 Rohingyas to Myanmar on April 25, 1996. The Bangladesh Rifles personnel had apprehended them while they were trying to enter into Bangladesh crossing the Teknaf border. They formally handed over the apprehended Rohingyas to the Myanmar Border Security Force (NASACA)." ${ }^{\prime 6}$ In February 1997, a total of 26,832 refugees were still awaiting repatriation. The director of the UNHCR's Regional Bureau for Asia said, "We are close to winding up the repatriation of the refugees from Bangladesh. We will now only focus on re-integration of the returnees in their homes. The situations in Myanmar have changed a lot. And the authorities there were extending all co-operation to the UNHCR. They have accepted the protection role of UNHCR and granted its international staff unrestricted access to all the returnees. But there is no guarantee that no fresh exodus will happen in future." ${ }^{17}$

In the meantime, the Myanmar authorities had set August 15, 1997, as the deadline for repatriation of all refugees. But repatriation continued to be faced with problems. "The government postponed scheduled repatriation of 200 refu- 
gees on July 23, 1997, following a law and order situation in two camps. Some 200 refugees from the Katupalong camp were due to go back home. A militant group from the Nayapara camp marched towards the Katupalong camp and asked the refugees not to return to Myanmar. Hundreds of refugees armed with bamboo sticks, bows and arrows forced out six officials and employees from the camp. They also damaged six huts and looted the goods that were to be distributed amongst refugees. Police arrested four refugees on charge of rioting." ${ }^{18}$ The rioting was very serious. "UNHCR officials from Dacca went to Cox's Bazar on July 24, 1997, morning to visit the camps and had talks with government officials on the latest developments. UNHCR officials however said that no force was being applied to make the refugees agree to be repatriated." ${ }^{19}$

An editorial in a Bangladesh newspaper commented "that the Bangladesh preparation fell short of taking the UNHCR officials along, which was why they were purportedly urging the Bangladesh authorities now to ensure voluntary repatriation. Bangladesh might have followed the procedure of sending the local UNHCR office the list of would-be returnees. Seemingly there had been some communication gap. But it was ironical that Bangladesh had to undergo a sensitivity test at the fag end of the send off process involving the last batch of 21,000 refugees" 20

A week after the riot, further talks were held. "A tripartite meeting among government officials, UNHCR representatives and leaders of Rohingya refugees was held in Cox's Bazar on July 30, 1997 which failed to resolve the problem that arose out of anti-repatriation stand taken by a section of the refugees. The meeting held for the consecutive day ended inconclusively, as leaders of Rohingya refugees were firm on their eight-point demand, which included suspension of repatriation till democracy was restored in Myanmar. Despite repeated assurances by both the government and UNHCR that their demands would be considered, the militant refugee leaders did not agree to give up their anti-repatriation agitation." ${ }^{21}$

There were suggestions from some quarters and international organizations that the remaining refugees who were unwilling to repatriate should be allowed to settle in Bangladesh. Bangladesh Foreign Minister Abdus Samad Azad said "that Bangladesh would not allow the remaining refugees to settle in the country permanently. It should be the responsibility of the international community to settle them elsewhere. Bangladesh with its limited resources should not bear the additional burden of allowing the refugees to stay in Bangladesh permanently."22 The remaining refugees maintained that the situation in Myanmar was far from normal. "Some refugees in Kutapalong camp claimed that 15,00o refugees who had been earlier repatriated to Myanmar came back to Bangladesh during the last couple of months to escape the wrath of the military junta." ${ }_{23}$ "The anti-repatriation group thought that if they could hold off the return of refugees until August 15, 1997, the deadline set by the Myanmar authorities to receive the Rohingya returnees, they would be able to stay back in Bangladesh for good." ${ }^{24}$ Officials of the Bangladesh Foreign Ministry observed that it would be difficult to complete repatriation by the August 15, 1997, deadline, because the process of convincing and counselling was still on.

The Bangladesh authorities conveyed their feeling of urgency to Myanmar authorities and requested an opportunity to sit across the table and discuss the issue. It was also made clear that lists of many refugees who had volunteered their names had been sent to Myanmar authorities for clearance, but no clearance could be obtained. Tension continued in the refugee camps. "Over a hundred persons, including 8 policemen, were injured in a clash between policemen and the refugees at Nayapara refugee camp in Cox's Bazar on October 21, 1997. Police said the trouble began when a group of refugees attacked the policemen as they tried to stop a clash between two rival groups of refugees."25

The refugee repatriation in 1998 and 1999 was negligible. There are still 20,00o to 22,00o refugees in Bangladesh. Negotiations between Bangladesh and Myanmar continue. It was agreed that after January 2000, fifty refugees would be repatriated every week under UNHCR supervision. But it is still to be seen when repatriation of all the refugees is actually completed.

\section{Lessons from the Rohingya Refugee Repatriation}

\section{Addressing causes of displacement}

Before undertaking any repatriation of refugees, it is necessary to address the causes of displacement. Rohingya displacement was the result of persecution by the Myanmar regime. The first step in such a situation was to persuade Myanmar to stop such acts of persecution and to take back its own citizens who were staying in Bangladesh as refugees. After the effective and timely intervention by the UN and the international community, the Myanmar authorities adopted a positive attitude to resolving the crisis. They admitted that the Rohingyas in the Arakan region had been subjected to many restrictions and that their freedom of movement and freedom of religion had been curtailed. They also agreed to improve the conditions in Arakan and signed an agreement with Bangladesh to that effect. Further, they agreed to negotiate with Bangladesh on the modalities to be followed for the repatriation of the refugees.

To bring about repatriation of refugees in any refugee 
situation, the UN and the international community should attempt to bring about reconciliation between the state and the refugees purely out of humanitarian consideration, without concern for any political issues. Such reconciliation must ensure the safety and security of the refugees and the enjoyment of their rights and privileges, just as any other citizens. In the case of the Rohingyas, if the UN and the international community had insisted that democracy first be restored in Myanmar, as many refugees had demanded, before repatriation was begun, it is unlikely that any repatriation could have occurred.

\section{Bilateral agreements as a basis of repatriation}

Neither Bangladesh nor Myanmar signed the 1951 Convention on the Status of Refugees or the 1967 Protocol. However, both countries entered into a bilateral agreement. The Myanmar authorities adopted a flexible approach by accepting refugees with proof of prior residence in Myanmar. Implementation was made more flexible as a result of a series of meetings held at the official level to sort out practical difficulties experienced during actual repatriation. Bilateral agreements are generally criticized on the grounds that such agreements may overlook the interest of the refugees, and that repatriation may be effected even when the situation is not conducive from the point of view of the refugees. But many countries prefer a bilateral framework for finding a solution, since they feel that involvement of a third party can unnecessarily internationalize the issue. The Rohingya refugee repatriation has shown that bilateral negotiations can bring about solutions to the satisfaction of all. Moreover, even within a bilateral framework, the international community can always intervene if the human rights of refugees are violated. What is of utmost importance from the point of view of the refugees is that a solution to the crisis be found, by effecting early repatriation, and if a bilateral mechanism can help bring it about it, that should be pursued. So there is a need to strengthen the bilateral mechanism rather than to view it with skepticism.

\section{Involvement of the UNHCR}

In case of repatriation within the framework of a bilateral agreement, the scope of involvement of the UNHCR is limited. The parties to the agreement should enjoy full freedom and support from the UNHCR. The role of the UNHCR should be only to oversee the repatriation, and if violation of the rights of refugees occurs, it should highlight such a violation and take up the issue with the authorities concerned. Refugees in most situations demand repatriation only under supervision of the UNHCR, but involvement of the UNHCR entails UNHCR clearance at every stage of repatriation. Such involvement can be counter-productive in many situations, so it is necessary to clearly spell out the scope of involvement of the UNHCR in each refugee repatriation process. The role of the UNHCR in repatriation under a multilateral agreement when the states have signed the 1951 Convention, and the role under a bilateral agreement, cannot be the same. Presently, the UNHCR follows the same approach in every repatriation.

\section{Voluntary Repatriation}

There were allegations that Bangladesh had repatriated many Rohingya refugees against their wishes, from the very beginning. The UNHCR, which was involved in the repatriation, despite initial reluctance of both countries, also protested against forced repatriation and withdrew itself from the repatriation process. The principle of nonrefoulement has to be strictly followed in any repatriation, but vested groups often manage to stall repatriation, taking umbrage at this principle. These groups sometimes manage to obtain the support of the UNHCR and succeed in their objective of stalling repatriation.

Bangladesh has accused the UNHCR and other NGOS of obstructing the repatriation and supporting groups totally opposed to repatriation under any circumstances. There were instances of armed refugee groups preventing willing refugees from repatriating. The refugee groups continued to oppose repatriation on the grounds that the situation in Myanmar had not yet returned to normal and that those who had been repatriated were being persecuted by the Myanmar regime. They also claimed that some refugees who had repatriated came back to Bangladesh. The UNHCR should have investigated such instances to effectively counter such allegations or to take up the issue with the appropriate authorities in order for them to take corrective action.

The question to be answered is, How can misuse of the issue of principle of non-refoulement be prevented, so that vested groups cannot stall repatriations?

\section{Law and order in camps}

There had been serious breaches of law and order in refugee camps on several occasions when refugee groups clashed against the security forces and among themselves. Such clashes were violent, and firearms were used, with loss of human life. Security forces had to open fire on several occasions to regain control. Proliferation of sophisticated firearms in refugee camps is a challenge of growing concern. Some refugee groups with arms were able to terrorize other refugees in the camps. Such acts of violence not 
only embarrass the host country but also harden its position. The host country tries to expedite repatriation and takes measures to deny asylum to refugee groups in the future, thereby undermining the entire principle of protection. Bangladesh had already prevented the entry of some Rohingyas by arresting them at the border and handing them over to the Border Police of Myanmar.

The question is whether there is a need to evolve a code for refugees, specifying their duties and obligations in the host country. The 1951 convention has specified the rights of refugees in the host country but is silent on this aspect.

\section{Period of Repatriation}

In the case of Rohingya refugees, repatriation started in 1992, but repatriation of all refugees has not been completed. In the initial years, repatriation of large numbers of refugees could be completed, but in the later years repatriation was very slow, and during some periods there was no repatriation at all. Any repatriation process is fraught with uncertainty, but still there is need to have a timeframe for repatriation. Refugee groups opposed to repatriation were allowing only small groups to return, as a part of a well-considered strategy to stall repatriation, and they succeeded in stretching out repatriation over eight years. The long period of repatriation creates avoidable complications. The Myanmar authorities applied stricter verification criteria for the later refugees. They also set a deadline for completion of repatriation because they did not want the process to continue indefinitely.

\section{Repatriation or resettlement of remaining refugees}

Out of 210,000 refugees, more than 190,000 refugees were repatriated. What was the justification for the remaining refugees to continue living in the camps? Those who have genuine fears of persecution duly established after thorough verification, case by case, may be allowed a longer period of asylum in the host country, or be resettled there or in a third country.

But the question is why other than these categories of refugees, remaining refugees should be allowed to stay on. Should the cessation of refugee status not be assumed as their non-return is deliberate, particularly when meaningful national protection is available?

\section{Conclusion}

Repatriation of Rohingya refugees from Bangladesh could be regarded as successful. The military regime in Myanmar adopted a positive approach on the issue of repatriation of the Rohingya refugees. This repatriation process has, how- ever, highlighted many important issues that need to be considered in order to promote more meaningful and effective refugee protection. In Myanmar, as a result of widespread human rights abuses, hundreds of thousands of people have fled the country and are living as refugees in camps or settlements in Thailand. The same approach of reconciliation and effective intervention by the international community, as was seen in the case of Rohingya refugees, can bring about voluntary repatriation to Myanmar of other refugee groups.

\section{Acknowledgement}

I am thankful to Prof. B. S. Chimni, School of International Studies, Jawaharlal Nehru University, for his guidance and valuable suggestions.

\section{References}

1. Jha Ganganath, Ethnic Politics in South East Asia and Quest for Identity (New Delhi: National Book Organization, 1997) 123.

2. Ibid., 135 .

3. Asian Recorder (New Delhi), 25-31 March 1992, 22211.

4. Ibid.

5. Jha Ganganath, op. cit., 136.

6. USCR, The World Refugee Survey (Washington, DC: USCR, 1993) 87.

7. Jha Ganganath, op. cit., 136.

8. Asian Recorder (New Delhi), 23-9 September 1992, 22591.

9. Ibid., 4-10 November 1992, 22687.

10. Ibid., 22687.

11. Ibid., 25 November-1 December 1992, 22735.

12. Ibid., 1-7 January 1993, 22816.

13. Public Opinion Trends (New Delhi), 17 July 1993, 1203-4.

14. Ibid., 21 March 1996, 263-4.

15. Ibid.

16. Ibid., 13 May 1996, 445.

17. Ibid., 11 November 1996, 1036.

18. Ibid., 21 August 1997, 797.

19. Ibid., 22 August 1997, 801-2.

20. Ibid., 27 August 1997, 818.

21. Ibid., 1 September 1997, 834 .

22. Ibid., 2 September 1997, 836 .

23. Ibid., 3 September 1997, 841-2.

24. Ibid.

25. Ibid., 16 November 1998, 1175.

K. C. Saha is a civil servant working for the Government of India. He has been working on issues concerning refugees and internally displaced persons in South Asia for the past six years. 